During low tide $O$. biplicata becomes quiescent, tending to aggregate, sometimes in very large numbers, near larger rocks or kelpholdfasts; this quiescence is observed even in fairly large tide pools. With the return of the first cold waves, the animals resume active locomotion and travel surprisingly rapidly and far. This behavior is ascribed to a lack of oxygen rather than the influence of the tidal pressure.

The varieties angelena and fucana, established by Oldroyd, are considered of no taxonomic validity. The door is left open for the variety parva, described from Point Abreojos in Lower California, being possibly a valid geographical variant.

\title{
BIBLIOGRAPHY
}

Gifford, D. S., and E. W. Gifford. 1941. Color variation in Olivella biplicata. Naut. 55 (1): 10-12.

1942. Color variation in Olivella biplicata in various localities. Naut. 56 (2): 43-48.

1944. California olivellas. Naut. 57 (3) : 73-80.

Keen, A. Myra. 1937. An abridged check list of west North American marine Mollusca. Stanford Univ. Press, pp. 1-84.

Oldroyd, T. S. 1918. Olivella biplicata angelena, var. nov. Naut. 32 (1) : 34-35.

1921. Some varieties of western olivellas. Naut. 34 (4): 117-119, p. V, figs. 4, 5, 6, 7 .

Oldroyd, I. Shepard. 1927. The marine shells of the west coast of North America. Vol. II, pt. 1: pp. 160-162; pl. 26, figs. 16, 16a, 17, 17a, 20, 20a, 23, 23a.

Stohler, R. 1952. Studies on mollusk populations: II. Naut. 65 (4) : 135-137.

\section{NEW PHYLLONOTUS FROM THE EASTERN PACIFIC}

BY A. MYRA KEEN

Stanford University, California

Having in recent years recommended the deletion of Phyllonotus (family Muricidae) from the roster of West American generic names, I now have the privilege of reinstating it, through a new discovery by an alert collector, Dr. Donald R. Shasky. To bring out the real significance of this find, one must review a little the history of the name Phyllonotus and its place in the Muricidae.

Phyllonotus Swainson, 1833, has, by convention, included several handsome muricid species that share a tendency toward 
brown color banding, pink or brown coloration around the aperture, and heavy varices that are not firmly soldered to the whorl, especially near the suture. The number of these varices per whorl and their complexity of form are classificatory characters not usually regarded as important. A few years ago, with the revival of Hexaplex Perry, 1811,1 complications began, for its type species would come within the boundaries of Phyllonotus in its customary sense. Nothing is gained, however, by synonymizing Phyllonotus. A possible way to preserve it would be to redefine both units; interestingly enough, a division could be made on the basis of morphology that would separate the species also into geographic groups. Hexaplex, with its East Indian type species and 3 West American forms-H. brassica (Lamarck, 1822), $H$. erythrostomus (Swainson, 1831), and $H$. regius (Swainson, 1821) 2 -would be restricted to the Pacific, whereas Phyllonotus would be entirely Atlantic in distribution. The type of Phyllonotus has usually been assumed to be the northern Caribbean P. pomum (Gmelin, 1791), for the actual monotypical type species, $P$. imperialis (Swainson, 1831) has been considered identical with it. Abbott (1958, p. 61) has challenged such a synonymy and, pointing out that the name Murex imperialis is a primary homonym, has renamed the type species as M. (Phyllonotus) margaritensis. His figures of the southern Caribbean form looked so disquietingly like Hexaplex regius that I speculated in print (Keen, 1959) on whether this might indeed be a Caribbean Hexaplex, in which case Phyllonotus as a name would be jeopardized more than ever. Opportunity since then to study several specimens and tabulation of all available size measurements have laid at rest my fears. I am con-

1 Hexaplex was based on several species, none indicated as type. Jousseaume in the 1880 's cited Murex cichoreus as type, but as this name was not actually in the original list, the first valid type selection was that of Hertlein and Strong, 1955: H. foliacea Perry = Murex cichoreus Gmelin, 1791 [better known under Lamarck's later name, $M$. endivia], an Indo-Pacific species.

2 This specific name has been attributed to Wood, 1828, but I can now report that it was actually validated earlier by Swainson in his Exotic Conchology, ed. 1, pt. 2, October, 1821, in the caption to an unnumbered plate. The name was overlooked entirely by Sherborn in his Index Animalium (one of his rare omissions), although earlier Sherborn and Reynell (Proc. Malac. Soc. London, $11(5)$ : 279, 1915) had cited Murex regius as validated by Swainson. This earliest use of the name was confirmed when Dr. S. S. Berry acquired recently a copy of Swainson's exceedingly rare book. 
vinced that Phyllonotus margaritensis is distinctive and not a Hexaplex. New limits, however, will have to be set for both groups, thus:

Hexaplex includes those shells with several varices (usually more than 41/2) per whorl, with well-developed frills and spines on the varices, especially along the shoulder of the whorl. Pink coloration of the aperture is characteristic in all species, from a trace of color at the posterior notch to complete suffusion of the entire aperture.

Phyllonotus comprises those shells with fewer than $41 / 2$ varices (mostly 3 to $31 / 2$ ) per whorl; varices have subdued spines or none at all. Pink coloration in the aperture is sporadic (i.e., in only one species and not invariably in that one).

Under the new arrangement, Phyllonotus, with $P$. pomum, $P$. margaritensis (or, as Dr. Clench [1959, p. 333] prefers, $P$. pomum margaritensis), and one or two West African species, would still be a group confined to the Atlantic were it not that a new and unquestionable eastern Pacific Phyllonotus has been found. Not only that, but the 8 specimens of the new form so far seen show sufficient morphologic and geographic differentiation to suggest a species and subspecies, which are here described.

\section{Phyllonotus Swainson, 1833}

Zool. Illust., ser. 2, vol. 3, pl. 100 (generic name only, no species names cited).

Type species (subsequent fixation, Swainson, 1833): Murex (Phyllonotus) imperialis, var. a $=$ M. imperialis Swainson, 1831 (not Fischer, 1807) $=$ M. (P.) margaritensis Abbott, 1958 (new name).

Phyllonotus peratus, new species. Pl. 10, fig. 6

Shell of medium size, with about 8 whorls, general color a dull grayish-brown, with obscure traces of underlying color bands of cinnamon to chestnut brown below the suture and on the base, with lighter areas between varices, and with darker spots on intervarical nodes; aperture white, suffused along the inner lip (also inside the outer lip of the holotype) with a warm creamy-yellow, and with four dark brown spots (ends of discontinuous color bands) showing on the outer lip, of which the uppermost spot continues above the aperture as a brown blotch. Sculpture of hollow spines along the varices, simulating 
those of Hexaplex on a small scale, with 2 (rarely 3) axial rows of sharply-defined intervarical nodes. Varices regularly 3 per whorl, each varix ending just short of the corresponding varix of the previous whorl, so that the rows of varices run diagonally up the spire. Spiral sculpture of several primary cords ( 8 on the last whorl of the holotype) that show best near the varices and may disappear between the nodes, with 6 to 8 uniform-sized spiral threads both on and between the primary cords. Aperture somewhat elliptical, the inner lip nearly smooth, rising into a free-standing parietal wall; outer lip serrate, with 14 irregular notches that reflect the primary and some of the secondary spiral sculpture. Operculum dark brown, ovate, with the nucleus sub-terminal and the right margin thickened within; outer surface not smooth but showing a radial depression, marking the inner edge of the thickening, and about 11 undulating concentric increments of growth. Posterior siphonal notch of moderate size, angular. Anterior canal narrowed, markedly recurved, nearly closed. Remnants of previous canals present (one on holotype, two on paratype), projecting to the left of the pillar.

Dimensions: Holotype, length, $66 \mathrm{~mm}$., width, $41 \mathrm{~mm}$., length of aperture, $24 \mathrm{~mm}$.; paratype, length, $69 \mathrm{~mm}$., width, $42 \mathrm{~mm}$., length of aperture, $25 \mathrm{~mm}$.

Repositories: Holotype, California Academy of Sciences Paleo. Type Collection, no. 7780; paratype, no. 7780A.

Type locality: Calif. Acad. Sci. loc. 17974, 14 mi. SE of Judas Point, Costa Rica, depth 42 fathoms (T. Crocker-N.Y. Zool. Soc. Exped. Sta. 214-D-1, $9^{\circ} 19^{\prime} 32^{\prime \prime}$ N. Lat., $84^{\circ} 29^{\prime} 30^{\prime \prime} \mathrm{W}$. Long., Mar. 1, 1938; mud and shell bottom).$^{3}$

Derivation of specific name: The Greeks had a word for this: their adjective peratos (transliteration), meaning, "on the opposite side, west." What more appropriate term could one ask?

Comparisons: Although some Phyllonotus pomum specimens are said to be spinose, none among the 40 available for comparison or among published illustrations equal $P$. peratus in this respect. Perhaps other specimens than the type lot of $P$. peratus lie, as they did in the California Academy's collection,

3 After this paper had been submitted for publication, I received a report from Mr. Martin D. Burkenroad that he had just got some peculiar specimens of a Hexaplex. My guess that they might be Phyllonotus proved correct. One of his 3 specimens, submitted for study, is a good $P$. peratus measuring $55 \mathrm{~mm}$. in height, $36.5 \mathrm{~mm}$. in diameter. The range of the species is therefore extended to Panama (trawled in 40 fathoms off Parita Bay, Gulf of Panama, Oct. 16, 1959). Relative proportions and sculpture of this specimen cast doubt on the validity of $P$. p . decoris as more than a color form, though again the southern specimen is slightly more spinose and darker in color than those from Mexico. 
mislabelled "Murex regius, juvenile." The 3 varices and lack of pink coloration, of course, refute this.

Phyllonotus peratus decoris, new subspecies. Pl. 10, figs. 4, 5, 7.

This may be only a color form, but the differences seem consistent. The aperture is brighter yellow than that of $P$. peratus, $s$. $s$, and the spire is a delicate coral pink for the first three or four whorls in some specimens. The untreated shell is lighter in color: a grayish-yellow. Etching with acid ( which had happened to several specimens before they reached their present owners) reveals an underlying color pattern of bright cinnamonbrown bands on a white ground, with small flecks of darker and lighter brown to the left of each node between varices. Sculpture is lower and more subdued. The shell seems also a little smaller, with a shorter anterior canal and, in most specimens, a slightly shorter spire.

Dimensions in $\mathrm{mm}$.

Length Width Length of aperture

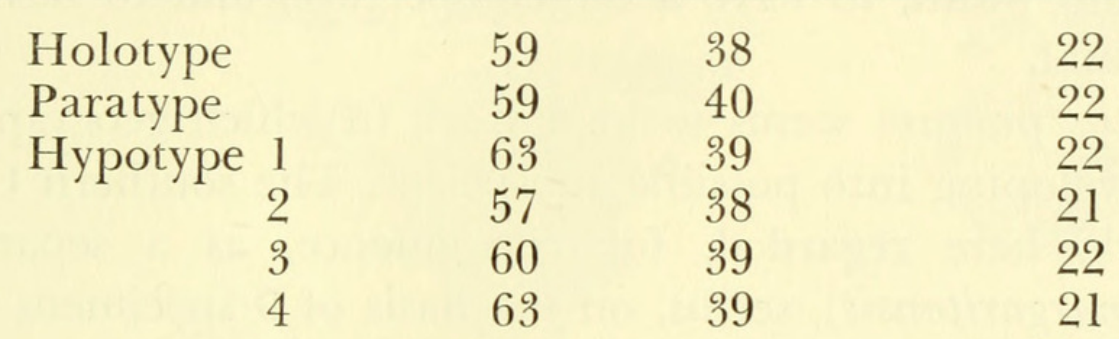

Repositories: Holotype, Stanford Univ. Paleo. Type Coll., no. 8753, courtesy of Dr. D. R. Shasky; Paratype, collection of Dr. Shasky; Hypotypes 1 to 3, collection of Captain Xavier Mendosa, Guaymas, Mexico; Hypotype 4, pl. 10, fig. 7, collection of Dr. Edwin J. Purcell, Tucson, Arizona, from west Mexico, exact locality and depth unknown.

Type locality: West Mexican coast near the Guatemalan border, depth about 15 fathoms; obtained from a shrimp boat by Dr. Donald R. Shasky.

Other localities: The hypotypes are also from shrimp boatsexact localities unknown but unquestionably from the West Mexican coast between the Gulf of Tehuantepec and Guaymas, Sonora, probably in the Salina Cruz area, all taken in nets of the Hector II, Cpt. Juan Rios, skipper.

Derivation of name: The adjective decoris is a Latin word meaning "elegant", "ornamented", or "beautiful", all appropriate terms for this shell.

Comparisons: The distinctions between $P$. peratus peratus and $P$. peratus decoris, though slight, are apparently consistent, the 
dimensions of the 6 specimens of the latter being almost identical except for the one slender variant shown in fig. 7. $P$. peratus, s. s., geographically a more southern form, seems to be somewhat the larger, with a higher spire and longer canal. Differences of both from $P$. pomum may be summarized thus: In $P$. pomum the varices become narrowed at the suture, giving the effect of being tucked under the preceding varix, whereas in $P$. peratus, s. $l$., they tend to flare and in P. peratus, s. s., to form several imbricating scales or laminae. In $P$. pomum the spiral sculpture consists of alternating primary and secondary ribs, striated by finer threads. In $P$. peratus the secondary sculpture is nearly even, with no additional fine threads. In $P$. pomum the intervarical spaces rise into one or two rounded axial ribs, but in $P$. peratus there are only isolated and sharp-pointed nodes in irregular rows. Graphical analysis of height-width ratios shows that although $P$. pomum is more variable, $P$. peratus tends to be longer for the width, to have a larger aperture, and to have a narrower canal.

Phyllonotus pomum seems to be a stock in which geographic races are developing into possible subspecies. The southern Caribbean stock, here regarded, for convenience, as a separate species ( $P$. margaritensis), seems, on the basis of 9 specimens for which measurements were available (as compared to 18, chosen as random, for $P$. pomum), to grow much larger (maximum length $110 \mathrm{~mm}$., as compared to 85 in $P$. pomum), and it is markedly wider for the length, with a larger aperture and a wider canal. One unnamed variant of $P$. pomum, represented in the Stanford Collection by 3 specimens from Colon, Panama, is nearly as spinous as $P$. peratus, but the shells are decidedly thinner and more slender, darker in color (almost a uniform chestnut brown in one specimen), with a much longer and nearly straight anterior canal. All these variations imply that the Miocene ancestor of the tropical-American Phyllonotus stock was a vigorous strain capable of a number of geographic variations that are now being realized in both the western Atlantic and the eastern Pacific.

Phyllonotus SP.

Pl. 10, figs. 2-3

A single specimen of a form that one would assume should be 


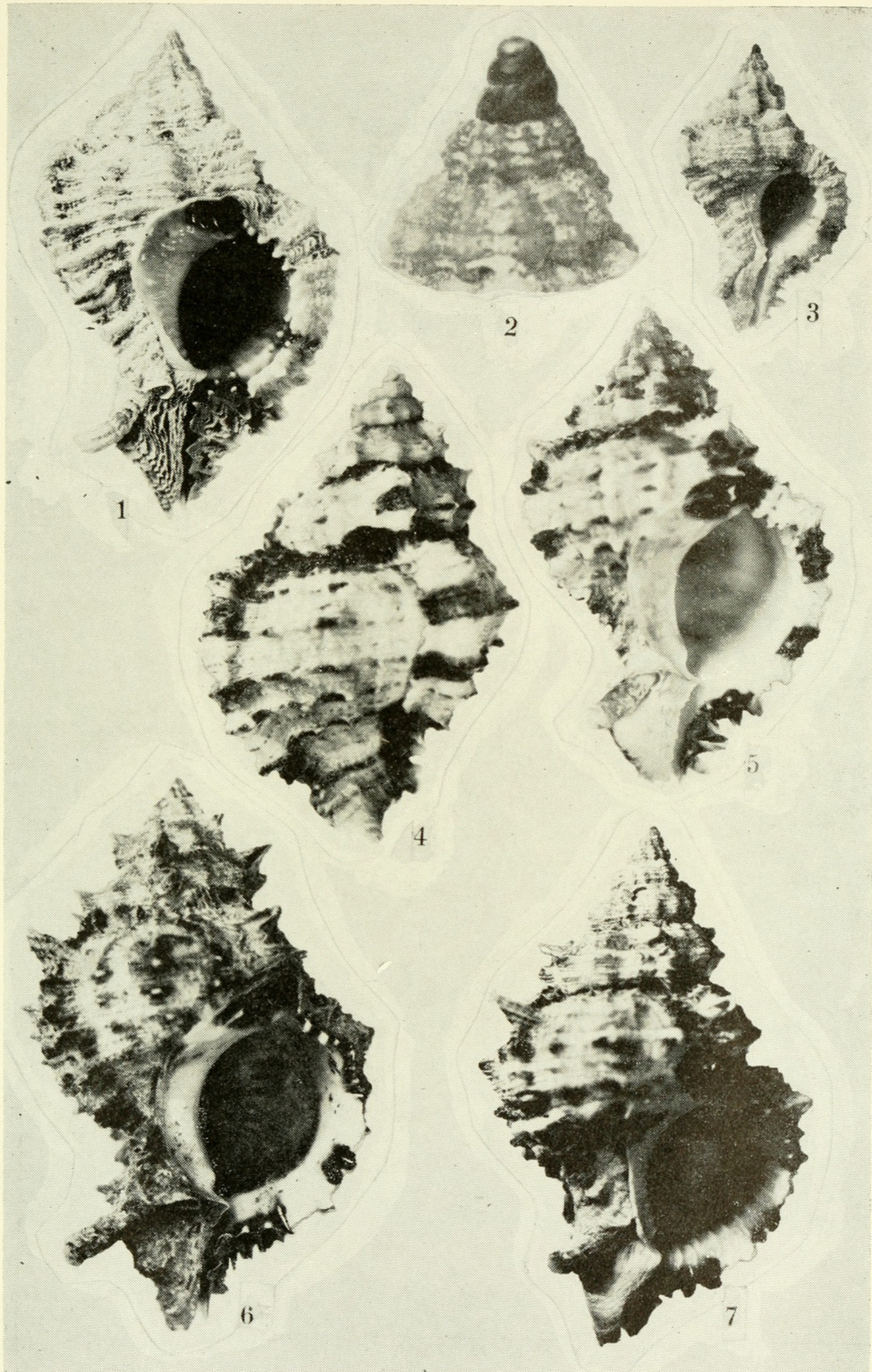

1 ( $\times 1)$, Phyllonotus pomum (Gmelin), Grand Bahama I., James McLean, coll. $2(\times 9)$ and $3(\times 1), P$. sp. 4, $5(\times 1), P$. peratus decoris Keen, holotype. $6(\times 1)$, P. peratus Keen, holotype. $7(\times 1), P$. peratus decoris Keen, hypotype 4. 


\section{$2 \mathrm{BHL}$ Biodiversity Heritage Library}

1960. "New Phyllonotus from the eastern Pacific." The Nautilus 73, 103-109. https://doi.org/10.5962/bhl.part.19796.

View This Item Online: $\underline{\text { https://www.biodiversitylibrary.org/item/34849 }}$

DOI: https://doi.org/10.5962/bhl.part.19796

Permalink: https://www.biodiversitylibrary.org/partpdf/19796

\section{Holding Institution}

MBLWHOI Library

\section{Sponsored by}

MBLWHOI Library

\section{Copyright \& Reuse}

Copyright Status: In copyright. Digitized with the permission of the rights holder.

Rights Holder: Bailey-Matthews National Shell Museum

License: http://creativecommons.org/licenses/by-nc-sa/3.0/

Rights: https://biodiversitylibrary.org/permissions

This document was created from content at the Biodiversity Heritage Library, the world's largest open access digital library for biodiversity literature and archives. Visit BHL at https://www.biodiversitylibrary.org. 